\title{
Maintenance of plasma-derived proteins at much lower concentrations in the uterine lumen of the rabbit: a kinetic study of passage
}

\author{
A. C. Kulangara \\ Department of Anatomy, The Medical College of Pennsylvania, Philadelphia, \\ Pennsylvania 19129, U.S.A.
}

\begin{abstract}
Summary. Human serum albumin (HSA) and human gamma globulin (HGG) in serum and uterine fluid of nonpregnant rabbits at various times after an i.v. injection $(100 \mathrm{mg} / \mathrm{kg})$ were measured by a radial immunodiffusion test using specific antisera. The HSA concentration in uterine fluid rose to a peak at $12 \mathrm{hr}$ when it was $11 \%$ of the serum concentration and then declined, whereas $\mathrm{HGG}$ reached a peak at $18 \mathrm{hr}(3.2 \%$ of serum level) and decreased thereafter. The HSA passed $2 \frac{1}{2}$ times faster than HGG, but both proteins equilibrated with uterine fluid in about $12-18 \mathrm{hr}$.

Steady state levels of HSA and HGG indicated that uterine fluid:serum ratios were $1: 10$ and $1: 20$, respectively. Similar ratios were found for total protein and rabbit serum albumin $(1: 10)$ and rabbit gamma globulin $(1: 20)$. Therefore, except when there is a local immune response, the uterine lumen contains only about $5 \%$ of the serum antibody concentration.

Available data in the mouse, rat and dog also indicate disparity between serum and uterine fluid protein levels.
\end{abstract}

\section{Introduction}

Considerable efforts have been made to control reproduction by immunization of the female against testicular, seminal or other antigens, in the expectation that antibodies will reach the uterine lumen and act on spermatozoa or the blastocyst (see review by Tyler \& Bishop, 1963; Menge, 1968; Bell \& McLaren, 1970). Although some reduction in fertilization rates and embryo and fetal survival was obtained, complete suppression was rarely achieved by this approach. These results may be explained by the fact that uterine fluid concentrations of proteins derived from blood do not exceed a tenth of their plasma concentration. We observed this restriction during an investigation of the passage of bovine serum albumin (BSA) from the mother to rabbit blastocysts (Crutchfield \& Kulangara, 1973). Other molecules and ions introduced into the rat and rabbit circulation have been detected in uterine fluid (Lutwak-Mann, Boursnell \& Bennett, 1960; Marley \& Robson, 1971; Sieber \& Fabro, 1971), but there are few kinetic studies (Conner \& Miller, 1973), which alone can establish maximum levels and periods for which they are obtained. This paper reports the kinetics of passage of human serum albumin (HSA) and human gamma globulin (HGG) and provides a measure of antibody levels attained in uterine fluid.

\section{Materials and Methods}

New Zealand White does, weighing $3 \cdot 0-3 \cdot 8 \mathrm{~kg}$, were obtained from commercial sources and housed in separate cages for 2 weeks before use. They were given single injections $(100 \mathrm{mg} / \mathrm{kg}$ body wt) of HSA or HGG into one ear vein and $2 \mathrm{~min}$ later about $0.5 \mathrm{ml}$ blood was collected from the other ear. At $6,12,18,24,48$ or $72 \mathrm{hr}$ after injection, uterine fluid was sampled as follows. A midventral incision was made under anaesthesia and the vaginal wall slit to expose the cervices. Each cervix was 
gently blotted or rinsed with saline and dried if it was smeared with blood. A mineral oil-coated thick-walled glass tube $(0.5 \mathrm{~mm}$ i.d., $1.5 \mathrm{~mm}$ o.d., $12 \mathrm{~cm}$ long) with a fire-polished tip was inserted through the cervix to the uterotubal junction. Mineral oil was applied to the outside of the uterine horn which was gently manipulated and suction exerted through the glass tube while it was slowly withdrawn. This procedure yielded 3-8 $\mu$ l fluid, uncontaminated with blood. A blood sample was collected from the heart at this time.

Proteins and antisera. The following proteins from Schwarz/Mann (Division of Becton, Dickinson \& Co., Orangeburg, New York) were used as standards: (i) HSA, crystallized human albumin, $100 \%$ pure; (ii) HGG, human 7S gamma globulin, chromatographically isolated, $100 \%$; (iii) RSA, crystallized rabbit serum albumin; (iv) RGG, rabbit $7 \mathrm{~S}$ gamma globulin, 100\% pure by immunoelectrophoresis. Their purity was verified by acrylamide gel electrophoresis before use.

For injection into rabbits, roughly $8 \%$ and $3 \%$ solutions of HSA and HGG (Fractions V and II: Schwarz/Mann) were prepared in saline, millipore filtered and their protein concentrations determined by the biuret test (Gornall, Bardawill \& David, 1949). The HSA and HGG content was also measured by radial immunodiffusion (see below).

The following antisera were used: (1) anti-HSA, prepared in New Zealand White rabbits in this laboratory; (2) anti-HGG, a horse antiserum against $\mathrm{H}$ and $\mathrm{L}$ chains of human IgG (Behring Diagnostics, Somerville, New Jersey); (3) anti-RSA, from Nutritional Biochemicals Corporation, Cleveland, Ohio; (4) anti-RGG, a goat antiserum from Behring Diagnostics. There were no detectable cross reactions when antisera against rabbit proteins were tested with HSA and HGG and when anti-HSA and anti-HGG were tested with rabbit proteins.

Radial immunodiffusion test. The HSA and HGG in serum and uterine fluid were measured by a radial immunodiffusion method, improved during years of use in this laboratory, which measures a minimum of $2-5 \mathrm{ng}$ and requires only $1 \mu \mathrm{l}$ samples. Microscope slides ( $3 \mathrm{in} \times 1 \mathrm{in}$ ) were coated with $0 \cdot 2 \%$ Epiagar (Colab Laboratories Inc., Glenwood, Illinois) and dried. Four strips of plastic electrical tape $(0.17 \mathrm{~mm}$ thick, Scotch no. 33) were layered at each end on the coated surface and another clean slide was placed on these tape supports so that there was a $0.68 \mathrm{~mm}$ space between the 2 slides. The combination was placed on a slide warmer at $55^{\circ} \mathrm{C}$.

A nominally $2 \%$ solution was prepared by adding $2 \mathrm{ml}$ veronal saline, $\mathrm{pH} 8 \cdot 2$ (7.422 g sodium veronal, $5.85 \mathrm{~g} \mathrm{NaCl}, 6.66 \mathrm{ml} 1 \mathrm{~N}-\mathrm{HCl}$, made up to 1 litre with distilled water), to $40 \mathrm{mg}$ Epiagar and dissolving the agar in a boiling water bath. The solution was then removed to a block heater at $55^{\circ} \mathrm{C}$. The antiserum was diluted, usually 1 in 40, with veronal saline. Two $\mathrm{ml}$ of the diluted fluid was warmed to $55^{\circ} \mathrm{C}$ and mixed with the $2 \%$ agar by pipetting 15-20 times. The mixture was then delivered into the $0.68 \mathrm{~mm}$ space described above and allowed to gel at room temperature for $15 \mathrm{~min}$, after which the upper slide could be slid off, leaving a thin layer of antiserum-agar on the lower slide.

A cutter made from a 17-gauge hypodermic needle was used to make 2 rows of 8 wells each in the $0.68 \mathrm{~mm}$ thick layer of gel. One $\mu \mathrm{l}$ each of standard dilutions $(10,20,40,80$ and $100 \mu \mathrm{g} / \mathrm{ml})$ and samples were placed in separate wells with a Beckman 153 microtitrator or Drummond microcaps. The slides were left in sealed moist dishes at room temperature for $24-36 \mathrm{hr}$, then removed and rinsed in cold $0.9 \% \mathrm{NaCl}$ for $5 \mathrm{~min}$. Precipitin ring diameters were measured to the nearest $0.01 \mathrm{~mm}$ under saline, using dark-ground illumination and a micrometer mounted on the stage of a dissecting microscope. When rings were too faint, they were intensified by immersing the slides in half-saturated ammonium sulphate solution for $15 \mathrm{~min}$. Sample concentrations were read from a straight line obtained by plotting the diameters of the standard rings. The error of the method was $3-4 \%$, except near the lower limit of $2-5 \mu \mathrm{g} / \mathrm{ml}$, where it was greater.

Co-precipitation and other nonspecific effects were checked by measuring known mixtures of 2 and 3 standard proteins with each antiserum and comparing with values obtained when measured singly.

Double diffusion test. Ouchterlony-type double diffusion was carried out as follows. Epiagar $(1 \%)$ in saline or veronal saline, with sucrose added to $10 \%$, was used to prepare thin gel layers as described above on 3 in $\times 2$ in slides. One central and six peripheral wells ( $3 \mathrm{~mm}$ diameter) were punched $4 \mathrm{~mm}$ apart. Runs were made in moist sealed dishes at room temperature for 3 days and patterns were photographed under dark-ground illumination without staining. 


\section{Results}

The double diffusion analyses with antisera against human and rabbit proteins showed that HSA (Pl. 1, Fig. 1) or HGG (Pl. 1, Fig. 2) occurred only in uterine fluid from injected rabbits, but the very similar RSA and RGG were identified in fluid from both normal and injected rabbits. Clearly, HSA and $H G G$ passed intact from the circulation into uterine fluid.

The HSA and HGG concentrations in uterine fluid at various times after injection are shown in Table 1. The HSA level reached a peak of $10.6 \%$ of serum concentration at $12 \mathrm{hr}$, after which it decreased and remained low up to $72 \mathrm{hr}$ (Pl. 1, Fig. 3). These results confirm previous observations with BSA (peak of $7-15 \%$ of serum level at $12 \mathrm{hr}$; Crutchfield \& Kulangara, 1973). The HGG entered the uterine fluid more slowly, reaching a peak of $3.2 \%$ of serum level at $18 \mathrm{hr}$ after injection. Since the antiserum used to measure HGG was specific to human IgG ( $H$ and $\mathrm{L}$ chains), these kinetics probably apply to IgG antibodies. Rabbit serum albumin (RSA) values were measured in 10 uterine fluid samples from 8 of the rabbits and they averaged $4 \cdot 5 \pm 1 \cdot 1$ (S.E.) $\mathrm{mg} / \mathrm{ml}$, which is about $12 \%$ of the serum concentration and similar to the HSA and BSA levels at their peaks.

Table 1. Human serum albumin (HSA) and human gamma globulin (HGG) in serum and uterine fluid of nonpregnant rabbits at various times after intravenous injection of a dose of $100 \mathrm{mg} / \mathrm{kg}$

\begin{tabular}{|c|c|c|c|c|c|c|}
\hline \multirow[b]{2}{*}{$\begin{array}{l}\text { Time of } \\
\text { sampling } \\
\text { (hr after } \\
\text { injection) }\end{array}$} & \multicolumn{3}{|c|}{ HSA concentration* in: } & \multicolumn{3}{|c|}{ HGG concentration* in : } \\
\hline & $\begin{array}{c}\text { Serum at } 2 \mathrm{~min} \\
\text { after } \\
\text { injection } \\
(\mathrm{mg} / \mathrm{ml})\end{array}$ & $\begin{array}{r}\text { Serum at } \\
\text { sampling } \\
(\mathrm{mg} / \mathrm{ml})\end{array}$ & $\begin{array}{l}\text { Uterine } \\
\text { fluid } \\
(\mu \mathrm{g} / \mathrm{ml})\end{array}$ & $\begin{array}{c}\text { Serum at } 2 \mathrm{~min} \\
\text { after } \\
\text { injection } \\
(\mathrm{mg} / \mathrm{ml})\end{array}$ & $\begin{array}{c}\text { Serum at } \\
\text { sampling } \\
(\mathrm{mg} / \mathrm{ml})\end{array}$ & $\begin{array}{l}\text { Uterine } \\
\text { fluid } \\
(\mu \mathrm{g} / \mathrm{ml})\end{array}$ \\
\hline 6 & $3 \cdot 21$ & 1.69 & $22 \pm 6$ & $3 \cdot 21$ & 1.99 & $21 \cdot 4 \pm 1 \cdot 9$ \\
\hline 12 & $3 \cdot 32$ & $1 \cdot 72$ & $183 \pm 60$ & $3 \cdot 21$ & 1.69 & $40 \cdot 7 \pm 8 \cdot 2$ \\
\hline 18 & 3.73 & $1 \cdot 42$ & $160 \pm 54$ & $3 \cdot 22$ & 1.49 & $47 \cdot 3 \pm 2 \cdot 9$ \\
\hline 24 & $3 \cdot 51$ & $1 \cdot 36$ & $24 \pm 5$ & 3.66 & $1 \cdot 54$ & $7 \cdot 1 \pm 4 \cdot 5$ \\
\hline 48 & $2 \cdot 53$ & 0.84 & $45 \pm 15$ & $3 \cdot 35$ & $1 \cdot 28$ & $1 \cdot 0$ \\
\hline 72 & $2 \cdot 98$ & 0.76 & $21 \pm 6$ & & & \\
\hline
\end{tabular}
time.

* Mean of 2-3 rabbit serum values and mean \pm S.E.M. of 4-6 uterine fluid samples at each sampling

The approximate rates of entry into uterine fluid, calculated from the initial parts of the curves for HSA and HGG (Pl. 1, Fig. 3), were 0.25 and $0.083 \mu \mathrm{g} / \mathrm{hr}$, respectively. A higher rate was recorded for BSA from the combined data of 100 and $200 \mathrm{mg} / \mathrm{kg}$ doses, but results of the lower dose alone indicated $0.19 \mu \mathrm{g} / \mathrm{hr}$ (Crutchfield \& Kulangara, 1973). The rates for the two albumins do not therefore differ significantly and are about $2 \frac{1}{2}$ times that for HGG. They are consistent with the smaller diffusion constant of $\mathrm{HGG}$ and suggest that passage may occur by diffusion.

The curves for HSA and HGG in serum showed no phase of immune clearance (Pl. 1, Fig. 3), indicating that there was no significant immune response to the injected foreign proteins. The decline of HSA and HGG in uterine fluid cannot therefore be attributed to an immune response.

\section{Discussion}

This study demonstrates that HSA and HGG introduced into the rabbit circulation pass into uterine fluid. Intravenously injected proteins have been detected in the uterine lumen of pregnant rabbits (Brambell, Hemmings, Henderson, Parry \& Rowlands, 1949; Kulangara \& Schechtman, 1962; Hemmings, 1973), but there are no such studies in nonpregnant rabbits. Our earlier report (Crutchfield \& Kulangara, 1973) and the present one seem to be the first quantitative and kinetic studies of protein passage into uterine fluid. They provide passage rates and steady state values. 
Comparison of rates of entry and the peak levels of BSA, HSA and HGG and the times at which HSA and HGG peaks occur show that albumins pass more rapidly than gamma globulins from the circulation into the uterine lumen (Pl. 1, Fig. 3). This difference may be due to faster diffusion of albumins or filtration according to molecular size during passage, or both. Roberts \& Courtice (1969) observed a similar difference between RSA and RGG levels in rabbit plasma and lymph.

Extensive analysis with radioactively labelled proteins in various species (see Matthews \& Freeman, 1967) has established that two properties may be measured from the peak attained in a body compartment by an intravenously injected tracer. The time required to reach the peak shows the time necessary for equilibration between blood and that compartment. The relative concentration at the peak is the steady state level. In the rabbit, albumin and gamma globulin equilibrate between plasma and extravascular fluid within 13-17 hr after injection (Matthews, 1957). Equilibration between serum and uterine fluid is equally rapid, since HSA and HGG reach their peaks at 12-18 hr (Pl. 1, Fig. 3). The steady state level of HSA in uterine fluid is $10.6 \%$, similar to the $7-15 \%$ for BSA (Crutchfield \& Kulangara, 1973), but different from the $3.2 \%$ for HGG (Table 1). These results are confirmed by measurements of RSA (this study) and RGG (unpublished) in normal uterine fluid, which are about $12 \%$ and $5 \%$ of their serum concentration. The $3.2 \%$ value obtained with $\mathrm{HGG}$ is comparable to $5 \%$ for RGG. Therefore, except when there is a local immune response in the uterus, the antibody level in uterine lumen will not exceed $5 \%$ of the serum level.

Uterine fluid proteins in the nonpregnant female are mostly plasma-derived, as shown by several types of evidence. (1) BSA, HSA and HGG pass rapidly from the circulation into the uterine lumen and reach proportions similar to those of rabbit proteins in serum and uterine fluid, indicating similar passage of RSA and RGG. (2) Among other possible sources of uterine fluid proteins, local synthesis by the uterus appears to be insignificant. Murray \& Daniel (1973) found little or no uptake of amino acids by the albumin fraction of luminal fluid. Influx of oviduct fluid, because of its much lower protein concentration (Hamner \& Williams, 1965), is more likely to decrease than add to protein levels in uterine fluid. (3) Quantitative estimates by moving boundary electrophoresis showed only one component $(11 \%$ of the total) in rabbit uterine fluid which was absent from serum (Stevens, Hafs \& Hunter, 1964). (4) By double diffusion and immunoelectrophoresis, Stevens et al. (1964) detected 5 antigens unique to uterine fluid, but in trace amounts. Similar results were reported for the rat (Ringler, 1961; Albers \& Castro, 1961). (5) Immunochemically specific measurements of RSA $(4.6 \mathrm{mg} / \mathrm{ml})$ and RGG $(0.57 \mathrm{mg} / \mathrm{ml})$ show that they add up to the total protein concentration $(4.8 \mathrm{mg} / \mathrm{ml})$ of uterine fluid (unpublished results). Thus, at least in the nonpregnant rat and rabbit, $90 \%$ or more of the uterine fluid proteins appear to be plasma proteins, although traces of locally synthesized ones may be present.

A comparison of serum and uterine fluid should therefore confirm the maintenance of proteins derived from the former at lower levels in the latter. Available estimates in the mouse, rat, rabbit and $\operatorname{dog}$ (Table 2) indicate that the total protein in uterine fluid is about $6 \mathrm{mg} / \mathrm{ml}(2 \cdot 07-14 \cdot 5)$, or $8-12 \%$ of serum concentration. Of the five methods of uterine fluid collection indicated in Table 2 , collection vessels left in the uterus probably yield fluid with abnormally high protein, e.g. higher than plasma (Hall et al., 1965). Ligation (Ringler, 1961) and cannulation (Wales, 1973) have been shown to produce slightly or distinctly higher protein content. Direct aspiration and luminal rinsing combined with volume estimation (Kulangara, 1972) seem to be reliable methods to obtain luminal concentration. The disparity between protein levels in fluid from Dutch Belted $(14.5 \mathrm{mg} / \mathrm{ml})$ and New Zealand White $(4.8 \mathrm{mg} / \mathrm{ml})$ rabbits may be a breed difference or due to greater variability of the earlier data. Serum proteins presumably enter uterine fluid via interstitital fluid, but since the latter may vary in composition and is not as readily sampled as blood, the uterine fluid: serum ratio is the more useful index. This ratio is roughly $1: 10$ for total protein and serum albumin and 1:20 for gamma globulin. The present results indicate that, for successful intrauterine therapy or contraception with antibodies, about 20 times the effective concentration in the uterine lumen will have to be achieved in the plasma.

A large difference in protein concentration between plasma and uterine fluid could be maintained by net outward transport or breakdown of protein by the uterus, or entry of fluid into the lumen together with outflow into the vagina, or a combination of these factors. At present, there seems to be 


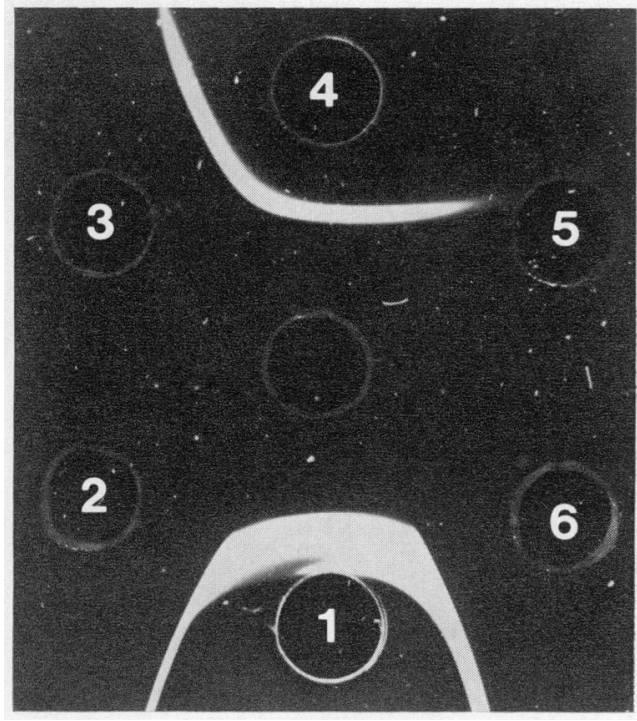

$1 \cdot 11.1$

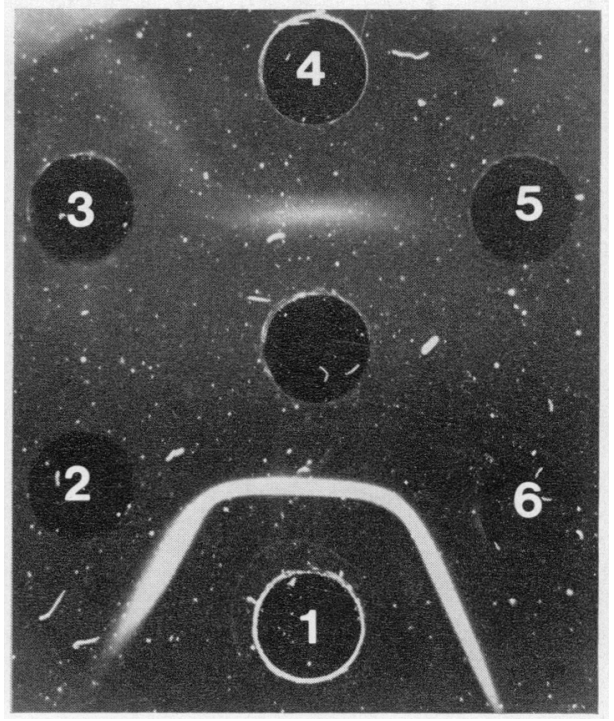

1.1..

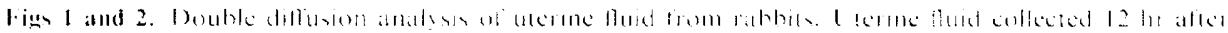

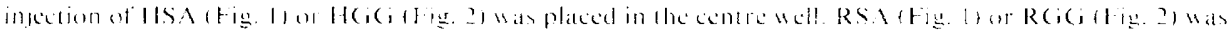

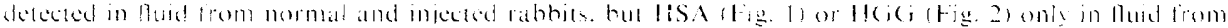

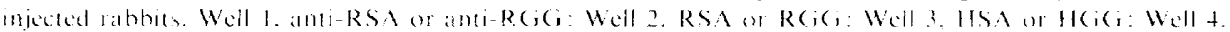

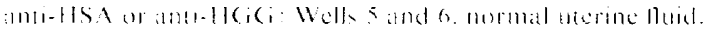
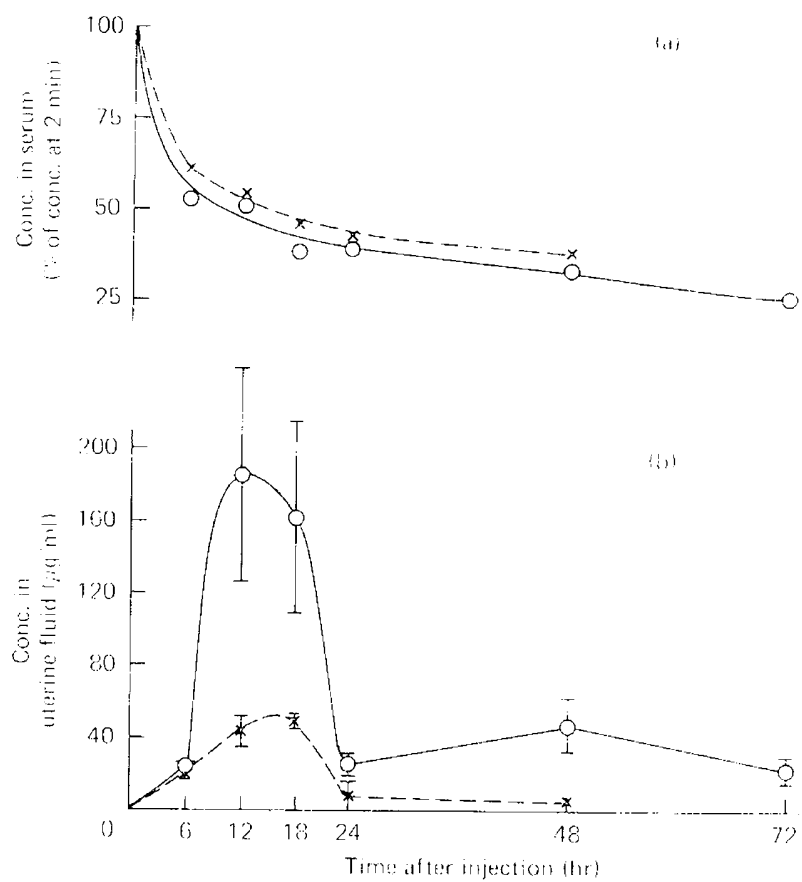

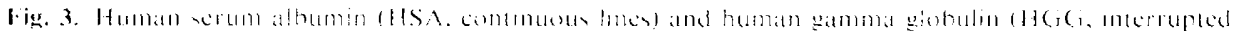

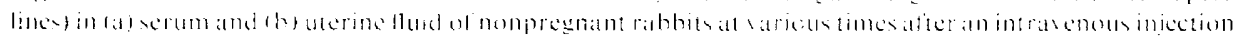
(1) 1001010. 
Table 2. Total protein concentration of fluid from the uterine lumen in nonpregnant females of various species

\begin{tabular}{|c|c|c|c|}
\hline & Method used to obtain fluid & $\begin{array}{c}\text { Mean (range) or } \\
\text { mean } \pm \text { S.D. }(\mathrm{mg} / \mathrm{ml})\end{array}$ & Reference \\
\hline Mouse & Uterine ligation for $7-11$ months & $8 \cdot 7^{*}(5 \cdot 2-12 \cdot 2)$ & Homburger et al. (1955) \\
\hline \multirow[t]{4}{*}{ Rat } & Direct aspiration & $2 \cdot 07 \pm 0.88$ & O'Shea (1972) \\
\hline & Direct aspiration $\ddagger$ & $3 \cdot 0^{*}(2 \cdot 5-3 \cdot 5)$ & Ringler (1961) \\
\hline & Uterine ligation + stilboestrol & $5 \cdot 1(1 \cdot 12-6 \cdot 53)$ & Shih et al. (1940) \\
\hline & Uterine ligation + oestradiol & 8.0 & Kunitake et al. (1965) \\
\hline \multirow[t]{2}{*}{ Rabbit } & Uterine ligation & $2 \cdot 7(1 \cdot 41-4 \cdot 0)$ & Shih et al. (1940) \\
\hline & Uterine ligation & $3.48(1.82-5 \cdot 13)$ & Stevens et al. (1964) \\
\hline N.Z. White & Luminal rinse + volume estimate & $4 \cdot 8(2 \cdot 6-7 \cdot 4)$ & $\begin{array}{l}\text { A. DiGaetano \& A. C. Kulangara } \\
\text { (unpublished) }\end{array}$ \\
\hline \multirow[t]{2}{*}{ Dutch } & Luminal rinse + volume estimate & $14 \cdot 5(5 \cdot 8-38 \cdot 6)$ & Kulangara (1972) \\
\hline & Cannulation & $22 \cdot 0 \pm 6 \cdot 0$ & Iritani et al. (1971) \\
\hline \multirow[t]{2}{*}{ Dog } & Uterine fistula + pilocarpine & $1 \cdot 21^{*}(0 \cdot 7-1 \cdot 72)$ & Shih et al. (1940) \\
\hline & Uterine ligation & $7 \cdot 53 *(5 \cdot 12-9 \cdot 94)$ & Shih et al. (1940) \\
\hline \multirow[t]{2}{*}{ Sheep } & Cannulation with or without ligation & $20 \cdot 0^{*}(10-30)$ & Wales (1973) \\
\hline & Cannulation & $\begin{array}{l}\$ 37 \cdot 0 \pm 13 \\
945 \cdot 0 \pm 10\end{array}$ & Iritani et al. (1969) \\
\hline \multirow[t]{3}{*}{ Woman } & Direct aspirationll & $39 \cdot 0(38-40)$ & $\begin{array}{l}\text { A. C. Kulangara \& B. A. Eskin } \\
\text { (unpublished) }\end{array}$ \\
\hline & Chamber left in uterus for $12 \mathrm{hr}$ & $50 \cdot 0(48-52)$ & Edwards et al. (1968) \\
\hline & Tube left in uterus for $48 \mathrm{hr}$ & $87 \cdot 5^{*}(80-95)$ & Hall et al. (1965) \\
\hline
\end{tabular}

\footnotetext{
* Midpoint of range.

$\dagger$ Day 0 of oestrous cycle.

$\ddagger$ At pro-oestrus and from oestrogen-treated castrates.

$\S 0-4$ days after oestrus.

I 5-16 days after oestrus.

II From 5 patients, all samples had a red tinge.
}

no evidence for sufficiently great outward transport or breakdown (Crutchfield \& Kulangara, 1973). However, oviduct fluid has been shown to enter the uterus of the rabbit (Hafez, 1963) and sheep (Belve \& McDonald, 1968). Water may also be transported into the lumen (Tuft \& Boving, 1970). These processes would tend to lower the protein concentration of uterine fluid. At least in the rat, there is periodic loss of this fluid through the vagina (Armstrong, 1968). It seems likely that a nonuniform influx and efflux of fluid to and from the uterine lumen maintains the low protein levels. The remarkable variability (coefficient of variation $50 \%$ or more) of volume and total protein (Kulangara, 1972) and the RSA and RGG concentrations (unpublished) in uterine fluid agrees with this conclusion.

\section{References}

Albers, H.J. \& Castro, M.N. (1961) The protein components of rat uterine fluid. An analysis of its antigens by immunoelectrophoresis and Ouchterlony gel diffusion technic. Fert. Steril. 12, 142-150.

ARMSTronG, D.T. (1968) Hormonal control of uterine lumen fluid retention in the rat. Am.J. Physiol. 214, 764-771.

Bell, E.B. \& McLaren, A. (1970) Reduction of fertility in female mice iso-immunized with a sub-cellular sperm fraction. J. Reprod. Fert. 22, 345-356.

Belve, A.R. \& McDonald, M.F. (1968) Directional flow of Fallopian tube secretion in the Romney ewe. J. Reprod. Fert. 15, 357-364.

Brambell, F.W.R., Hemmings, W.A., Henderson, M., PARRY, H.J. \& Rowlands, W.T. (1949) The route of antibodies passing from the maternal to the foetal circulation in rabbits. Proc. $R$. Soc. B, 136, 131-144.

Connfr, E.A. \& Miller, J.W. (1973) The distribution of selected substances into rat uterine luminal fluid. J. Pharmac. exp. Ther. 184, 291-298.

Crutchfield, F.L. \& Kulangara, A.C. (1973) Passage of bovine serum albumin from the mother to rabbit blastocysts. I. Passage from the circulation to uterine lumen. J. Embryol. exp. Morph. 30, 459-469.

Eowards, R.G., TAlberT, L., IsRaelstam, D., Nino, H.V. \& Johnson, M.H. (1968) Diffusion chamber for exposing spermatozoa to human uterine secretions. Am. J. Obstet. Gynec. 102, 388-396.

Gornall, A.G., Bardawill, C.J. \& David, M.M. (1949) Determination of serum proteins by means of 
the biuret reaction. J. biol. Chem. 177, 751-766.

HAFez, E.S.E. (1963) The uterotubal junction and the luminal fluid of the uterine tube in the rabbit. Anat. Rec. 145, 7-12.

Hall, H.H., Sedlis, A., Chabon, I. \& Stone, M.L. (1965) Effect of intrauterine stainless steel ring on endometrial structure and function. Am.J. Obstet. Gynec. 93, 1031-1041.

Hamner, C.E. \& Williams, W.L. (1965) Composition of rabbit oviduct secretions. Fert. Steril. 16, 170-176.

Hemmings, W.A. (1973) Transport of maternal antibodies to the rabbit foetus. In Proc. 1 st Int. Congr. Immun. Obstet. Gynec. pp. 252-264. Eds A. Centaro, N. Carretti \& G. M. Addison. Excerpta Medica Foundation, Amsterdam.

Homburger, F., Grossman, M.S. \& Tregier, A. (1955) Experimental hydro-uteri (hydrometra) in rodents and some factors determining their formation. Proc. Soc. exp. Biol. Med. 90, 719-723.

IrITANI, A., Gomes, W.R. \& VANDEMaRK, N.L. (1969) Secretion rates and chemical composition of oviduct and uterine fluids in ewes. Biol. Reprod. 1, 72-76.

Iritani, A., Nishikawa, Y., Gomes, W.R. \& VANDemark, N.L. (1971) Secretion rates and chemical composition of oviduct and uterine fluids in rabbits. J. Anim. Sci. 33, 829-835.

KULANGaRA, A.C. (1972) Volume and protein concentration of rabbit uterine fluid. $J$. Reprod. Fert. 28, 419425.

Kulangara, A.C. \& Schechtman, A.M. (1962) Passage of heterologous serum proteins from mother into fetal compartments in the rabbit. Am.J. Physiol. 203, 1071-1080.

Kunitake, G.M., Nakamura, R.M., Wells, B.G. \& MoXer, D.L. (1965) Studies on uterine fluid. I. Disc electrophoretic and disc-gel Ouchterlony analyses of rat uterine fluid. Fert. Steril. 16, 120-124.

Lutwak-ManN, C., Boursnell, J.C. \& Bennett, J.P. (1960) Blastocyst-uterine relationships: uptake of radioactive ions by the early rabbit embryo and its environment. J. Reprod. Fert. 1, 169-185.

MARley, P.B. \& Robson, J.M. (1971) Passage of sodium into the uterine lumen of the rat during the sexual cycle and under the influence of steroidal hormones. J. Reprod. Fert. 26, 287-296.
Matthews, C.M.E. (1957) The theory of tracer experiments with ${ }^{131} \mathrm{I}$-labelled plasma proteins. Phys. Biol. Med. 2, 36-53.

Matthews, C.M.E. \& Freeman, T. (1967) The albumin pool. In Compartments, Pools and Spaces in Medical Physiology, pp. 299-319. Eds E. E. Bergner \& C. C. Lushbaugh. U.S. Atomic Energy Commission, Division of Technical Information, Oak Ridge, Tennessee.

MENGE, A.C. (1968) Fertilization, embryo and fetal survival rates in rabbits isoimmunized with semen, testis and conceptus. Proc. Soc. exp. Biol. Med. 127, 1271-1275.

MURRAY, F.A. \& DANIEL, J.C., JR (1973) Synthetic pattern of proteins in rabbit uterine flushings. Fert. Steril. 24, 692-697.

O'SHEA, J.D. (1972) Uterine fluid and the duration of pseudo-pregnancy following transection of the uterus in the rat. J. Reprod. Fert. 29, 57-64.

RINGLER, I. (1961) The composition of rat uterine luminal fiuid. Endocrinology 68, 281-291.

Roberts, J.C. \& Courtice, F.C. (1969) Measurements of protein leakage in the acute and recovery stages of a thermal injury. Aust. J. exp. Biol. med. Sci. 47, 421-433.

SHiH, H.E., KenNedy, J. \& Huggins, C. (1940) Chemical composition of uterine secretions. Am.J. Physiol. 130, 287-291.

SiEBER, S.M. \& FABRo, S. (1971) Identification of drugs in the preimplantation blastocyst and in the plasma, uterine secretion and urine of the pregnant rabbit. J. Pharmac. exp. Ther. 176, 65-75.

Stevens, K.R., Hafs, H.D. \& Hunter, A.G. (1964) Immunochemical and electrophoretic properties of oestrous rabbit uterine fluid proteins obtained by uterine ligation. J. Reprod. Fert. 8, 319-324.

TuFT, P.H. \& Boving, B.G. (1970) The forces involved in water uptake by the rabbit blastocyst.J. exp. Zool. 174, 165-172.

TYLER, A. \& BISHOP, D.W. (1963) Immunological phenomena. In Mechanisms Concerned With Conception, pp. 397-482. Ed. C. G. Hartman. Pergamon Press, New York.

Wales, R.G. (1973) The uterus of the ewe. II. Chemical analysis of uterine fuid collected by cannulation. Aust. J. biol. Sci. 26, 947-959.

Received 23 May 1975 